\title{
KEDUDUKAN HUKUM PENGGUNAAN PASAL PERCOBAAN PERZINAHAN DALAM PRAKTIK PERADILAN
}

\author{
Handoko Alfiantoro ${ }^{1}$ \\ Kejaksaan Negeri Situbondo, Situbondo Jawa Timur \\ handokoalfiantoro@yahoo.co.id
}

\begin{abstract}
This study discusses the legal position of the use of trial articles of adultery in judicial practice. In addition to the peculiarity of the notion of adultery according to the law, the complexity of the terms for denouncing adultery takes relatively long process; hence, the settlement of such adultery criminal cases slow. Another problem arises when voltoid delicts in the Article of adultery have not yet been completed and included in the trial category, the formulations of adultery trial has not been confirmed, and differences in interpretating the beginning and the trial for adultery are often subject to debate. The limitation of the problem in this study is how to try the legal position of adultery in the practice of justice. This article was compiled using normative juridical research methods through the Law approach, comparative approach and conceptual approach, which aims to critically examine the Legal Position of the Use of Articles of Adultery Trials in Judicial Practices. The results of this study explain that formally the trial adultery is categorized as a criminal offense, but as long as it is not explicitly stipulated in the Criminal Code regarding the trial of crimes that cannot be convicted, then the crime can be subject to normative jurisdiction. Practically the judiciary must be examined further to the extent that the trial article for adultery can be logic and proven. This calls for a concrete revision regarding the trial clause of adultery.
\end{abstract}

Keywords: Crime, Trial, Adultery

\begin{abstract}
ABSTRAK
Penelitian ini membahas kedudukan hukum penggunaan Pasal percobaan perzinahan dalam praktik peradilan. Adanya kekhasan pengertian tentang perzinahan menurut hukum dengan kompleksitas syarat-syarat pengaduan perzinahan yang relatif panjang membuat penyelesaian perkara tindak pidana perzinahan berjalan lambat. Persoalan lain kemudian muncul ketika voltoid delict dalam Pasal tindak pidana perzinahan belum sampai selesai dan dimasukkan dalam kategori percobaan, batasan formulasi yang belum tegas tentang percobaan perzinahan, serta perbedaan penafsiran tentang permulaan pelaksanaan dan perbuatan persiapan membuat penggunaan Pasal percobaan perzinahan seringkali menjadi bahan perdebatan. Batasan masalah dalam penelitian ini yaitu bagaimana kedudukan hukum percobaan perzinahan dalam praktik peradilan. Artikel ini disusun dengan menggunakan metode penelitian yuridis normatif melalui pendekatan UndangUndang, pendekatan perbandingan dan pendekatan konseptual, yang bertujuan untuk mengkaji secara kritis tentang Kedudukan Hukum Penggunaan Pasal Percobaan Perzinahan dalam Praktik Peradilan. Hasil penelitian ini menjelaskan bahwa secara formal Pasal percobaan perzinahan termasuk kategori tindak pidana kejahatan, namun selama tidak diatur secara tegas dalam KUHP berkenaan percobaan kejahatan yang tidak dapat dipidana, maka kejahatan tersebut secara yuridis normatif tetap dapat dikenakan. Secara praktik peradilan harus dikaji lebih jauh lagi sampai batas mana Pasal percobaan perzinahan dapat dilogikakan secara nalar dan dibuktikan. Hal inilah yag membuat harus ada revisi konkrit terkait klausul pasal percobaan perzinahan.
\end{abstract}

Kata Kunci: Tindak Pidana, Percobaan, Perzinahan

\footnotetext{
${ }^{1}$ Submit : 15.12.2018 Editing - 1: 16.12.2018 Review - 1: 21.12.2018 Review - 2: 21.12.2018

Editing - 2: 25.12.2018 Roduction : 1.1.2019
} 


\section{Pendahuluan}

Seiring dengan perkembangan zaman, maka perilaku masyarakat pun semakin berkembang dan tidak sedikit perilaku maupun tindakan masyarakat yang mencerminkan tidak adanya ketaatan terhadap adanya norma, salah satunya berkaitan dengan norma kesusilaan.

Kesusilaan (zedelijkheid) adalah mengenai adat kebiasaan yang baik dalam berhubungan antar berbagai anggota masyarakat, tapi yang khusus sedikit banyak mengenai kelamin (seks) seorang manusia, sedangkan kesopanan (zeden) pada umumnya mengenai adat kebiasaan yang baik. ${ }^{2}$

Keamanan dan ketertiban dalam masyarakat akan tercipta dan terpelihara apabila setiap anggota masyarakat menaati peraturan (norma) yang ada dalam masyarakat itu sendiri, dan untuk ditaati diperlukan suatu sanksi bagi pelanggarnya. Adapun peraturan hidup kemasyarakatan yang bersifat mengatur dan memaksa untuk menjamin tata tertib masyarakat lazim disebut dengan norma hukum.

Selanjutnya Moeljatno berpendapat bahwa bagian dari keseluruhan hukum yang berlaku di suatu negara yang mengadakan dasar-dasar dan aturan untuk menentukan perbuatan-perbuatan yang tidak boleh dilakukan/dilarang dengan ancaman sanksi berupa pidana tertentu bagi yang melanggar aturan tersebut disebut Hukum Pidana. ${ }^{3}$

Dalam sistem hukum pidana Indonesia mengenal asas nullum delictum nulla poena sine praevia lege poenali, yang artinya tidak ada delik, tidak ada pidana tanpa peraturan terlebih dahulu. ${ }^{4}$ Berdasarkan asas tersebut dapat dikatakan bahwa tidak ada perbuatan yang dilarang dan diancam dengan pidana jika tidak ditentukan terlebih dahulu dalam peraturan perundangundangan. Suatu perbuatan yang merupakan perbuatan pidana akan diselesaikan melalui proses persidangan menggunakan tata cara yang dianut dalam hukum acara pidana.

${ }^{2}$ M. Sudrajat Basar, Tindak Tindak Pidana Tertentu di Dalam KUHP, Bandung: CV Remaja Karya, 1986, hlm. 161

${ }^{3}$ Moeljatno, Asas Asas Hukum Pidana, Jakarta: Rineka Cipta, 2002, hlm. 1.

${ }^{4}$. Ibid., hlm. 23. 
Lebih lanjut Moeljatno menyatakan bahwa perbuatan yang oleh hukum pidana dilarang dan diancam dengan pidana dinamakan perbuatan pidana. ${ }^{5}$ Berdasarkan hal ini, maka setiap orang yang melakukan perbuatan pidana akan dikenai sanksi berupa penjatuhan pidana tertentu seperti yang diatur dan diancamkan dalam setiap rumusan delik di dalam Kitab Undang-Undang Hukum Pidana (KUHP) maupun peraturan perundang-undangan khusus di luar KUHP.

Konsekuensi perkembangan perilaku dan perbuatan masyarakat berdampak pula pada perbuatan pidana yang semakin kompleks dan berkembang. Begitu pun dengan kasus di bidang kesusilaan, dimulai dengan semakin banyaknya celah para pemuda dan pemudi melakukan praktik perzinahan karena tidak dapat dipidana dengan dasar tidak ada aturan yang mengatur secara tegas dalamnya, sampai kasus perzinahan dengan berbagai modus dan motif yang dilakukan.

Berbicara mengenai perzinahan, bukanlah hal yang tabu untuk didiskusikan sepanjang berimplikasi lebih baik untuk hukum pidana ke depan. Seseorang dapat dikenakan pasal perzinahan apabila telah memenuhi alat bukti yang cukup dan memenuhi unsur-unsur yang telah ditetapkan oleh Undang-Undang.

Dalam Hukum Pidana ada tindak pidana yang dilakukan sampai selesai, ada pula tindak pidana yang dilakukan tidak sampai selesai karena bukan kehendak dari diri pelaku, melainkan karena faktor-faktor eksternal yang mempengaruhinya yang lazim disebut dengan percobaan.

Pada dasarnya sangat jarang sekali pasal percobaan perzinahan dikenakan kepada pelaku oleh karena relatif sulitnya pembuktian untuk dilogikakan sampai batas mana secara konkrit perbuatan yang dapat dikategorikan sebagai percobaan perzinahan. Hal lain juga belum adanya yurisprudensi dari Mahkamah Agung Republik Indonesia yang memutuskan berkaitan dengan percobaan perzinahan, namun demikian dalam KUHP juga tidak diatur tentang larangan bahwa pasal percobaan perzinahan tidak dapat dikenakan.

\footnotetext{
${ }^{5}$ Moeljatno, Asas Asas Hukum Pidana ...Opcit, hlm.2.
} 
Penelitian yang membahas tentang tindak pidana perzinahan secara umum cukup banyak dilakukan oleh para peneliti terdahulu. Berdasarkan hasil penelusuran terhadap beberapa literatur yang telah dilakukan, maka setidaknya ditemukan beberapa literatur yang membahas mengenai permasalahan ini.

Pertama, Nita Triani, Eko Raharjo, Dona Raisa Monica dengan judul Analisis Putusan Hakim dalam Membebaskan Pelaku yang Didakwa Melakukan Tindak Pidana Perzinahan (Studi Putusan Nomor: 89/Pid/2017/Pt.Tjk) pada tahun 2018 yang dalam penelitiannya tersebut membahas tentang dasar pertimbangan hakim dalam membebaskan pelaku yang didakwa melakukan tindak pidana perzinahan pada Putusan Nomor. 89/Pid/2017/PT.Tjk. Adapun hasil penelitian tersebut menyatakan bahwa dasar pertimbangan hakim dalam membebaskan pelaku yang didakwa melakukan tindak pidana perzinahan adalah Terdakwa tidak terbukti secara sah dan meyakinkan memenuhi rumusan unsur dalam Dakwaan Tunggal yang diajukan oleh Jaksa Penuntut Umum, oleh karena itu Terdakwa harus dinyatakan tidak bersalah dan dibebaskan dari dakwaan tunggal tersebut (Vrijspraak) dan hak Terdakwa dalam kemampuan, kedudukan dan harkat serta martabatnya harus dipulihkan (direhabilitasi). ${ }^{6}$

Kedua, H. Iman Hidayat dengan judul Analisis Normatif Tindak Pidana Perzinahan Dilihat dalam Perspektif Hukum Islam pada tahun 2016 yang dalam penelitiannya tersebut membahas tentang pengaturan hukum pidana nasional terhadap tindak pidanaperzinahan serta bagaimana pengaturan hukum pidana Islam terhadap tindak pidana perzinahan. Adapun hasil penelitian tersebut menyatakan bahwa terdapat perbedaan mendasar antara konsep tindak pidana perzinaan menurut hukum Islam dibandingkan dengan konsep perzinaan menurut KUHP. Perbedaan-perbedaan tersebut terutama disebabkan oleh adanya perbedaan latar belakang. Tindak pidana perzinahan pasal 2 dan 4 dalam KUHP dilatarbelakangi oleh asas monogamy yang dilingkupi oleh kondisi masyarakat yang berpaham individualisme dan liberalisme.

${ }^{6}$ Nita Triani, Eko Raharjo dan Dona Raisa Monica, “Analisis Putusan Hakim dalam Membebaskan Pelaku yang Didakwa Melakukan Tindak Pidana Perzinahan (Studi Putusan Nomor: 89/Pid/2017/Pt.Tjk)", Jurnal Skripsi Fakultas Hukum Universitas Lampung, 2018, hlm. 1 
Sedangkan tindak pidana menurut Hukum Islam dilatarbelakangi oleh perintah Allah yang di implementasikan didalam Al-Qur'an dan as-Sunnah. ${ }^{7}$

Mencermati dua penelitian terdahulu di atas, maka dapat dikatakan penelitian ini berbeda dengan kedua penelitian tersebut, adapun unsur kebaruan dalam penelitian ini terletak pada kajian utama masing-masing penelitian, yaitu penelitian ini menjadikan isu hukum kedudukan hukum percobaan perzinahan dalam praktik peradilan sebagai kajian utamanya, sedangkan pada penelitian terdahulu di atas mengkaji studi putusan Nomor: 89/Pid/2017/Pt.Tjk dalam pembebasan pelaku yang didakwa melakukan tindak pidana perzinahan serta pada kajian yang ke dua lebih membahas pada pengaturan hukum pidana Islam terhadap tindak pidana perzinahan.

\section{Rumusan Masalah}

Berdasarkan uraian di atas, maka dapat dirumuskan permasalahan dalam penelitian ini yaitu bagaimana kedudukan hukum percobaan perzinahan dalam praktik peradilan.

\section{Tujuan Penelitian}

Adapun tujuan dari penelitian ini adalah untuk mengkaji secara mendalam kedudukan hukum percobaan perzinahan dalam praktik peradilan.

\section{Metode Penelitian}

\subsection{Jenis Penelitian}

Jenis Penelitian yang digunakan yuridis normatif yaitu dengan mengkaji ketentuan perundang-undangan yang berlaku. Penelitian normatif berfungsi untuk memberi argumentasi yuridis ketika terjadi kekosongan, kekaburan, dan konflik norma hukum. ${ }^{8}$

\footnotetext{
${ }^{7}$ H. Iman Hidayat, “ Analisis Normatif Tindak Pidana Perzinahan Dilihat dalam Perspektif Hukum Islam”, Jurnal Ilmiah Universitas Batanghari Jambi Vol.16 No.1 Tahun 2016, hlm. 45

${ }^{8}$ I Made Pasek Diantha, Metodologi Penelitian Hukum Normatif Dalam Justifikasi Teori Hukum, Jakarta: Prenada Media Group, 2017, hlm. 12
} 


\subsection{Pendekatan Penelitian}

Pendekatan yang digunakan adalah pendekatan Undang-Undang (statue approach) dimana lebih menekankan kepada peraturan-peraturan yang ada. Selain itu itu juga digunakan pendekatan pendekatan perbandingan (comparative approach) dan pendekatan konseptual (conceptual approach $)^{9}$

\subsection{Bahan Hukum}

Penelitian ini menggunakan bahan hukum kepustakaan yang dapat berupa Peraturan perundang-undangan, dokumen, buku-buku, laporan, arsip, dan literatur yang berkaitan dengan masalah yang diteliti. Bahan hukum yang akan digunakan dalam penelitian ini adalah:

\subsubsection{Bahan hukum primer}

Bahan hukum primer yaitu bahan-bahan hukum pokok yang mengikat. Dalam penulisan ini, digunakan bahan hukum primer berupa Kitab Undang-Undang Hukum Pidana (KUHP).

\subsubsection{Bahan hukum sekunder}

Bahan hukum sekunder yaitu bahan-bahan hukum yang mendukung dan memperjelas bahan hukum primer yang berupa dokumen-dokumen resmi, meliputi karya tulis, buku-buku teks, jurnal-jurnal hukum dan komentar-komentar atas putusan pengadilan.

\subsubsection{Bahan non-hukum}

Bahan yang memberikan penjelasan maupun petunjuk terhadap bahan hukum primer maupun sekunder yang telah ada seperti Kamus Besar Bahasa Indonesia dan lain sebagainya yang digunakan untuk mencari istilah-istilah dalam rangka menjelaskan hal-hal yang digunakan dalam bahan hukum primer maupun bahan hukum sekunder.

${ }^{9}$ Peter Mahmud Marzuki, Penelitian Hukum, Jakarta: Kencana Prenada Media Group, 2008, hlm. 93 


\subsection{Teknik Pengumpulan Data}

Teknik Pengumpulan data yang akan digunakan dalam penelitian hukum ini adalah studi kepustakaan yang terbatas pada penggunaan dokumen dan bahan pustaka. Pengumpulan data dilakukan dengan cara mengumpulkan data-data tertulis yang berkaitan dengan masalah yang diteliti.

\subsection{Metode Analisis Data}

Terkait dengan metode analisis bahan hukum yang digunakan dalam tulisan ini menggunakan metode deduktif, yaitu berpangkal dari prinsipprinsip dasar kemudian menghadirkan objek yang hendak diteliti, dengan kata lain, berpangkal dari prinsip-prinsip umum menuju prinsip-prinsip khusus. ${ }^{10}$

\section{Hasil Penelitian dan Pembahasan}

\subsection{Pengertian Tindak Pidana Percobaan Perzinahan}

Tindak pidana berasal dari suatu istilah dalam hukum belanda yaitu strafbarfeit. Ada pula yang mengistilahkan menjadi delict yang berasal dari bahasa latin delictum. Simons menerangkan bahwa strafbarfeit adalah adalah perbuatan atau tindakan yang diancam dengan pidana oleh Undang-Undang, bertentangan dengan hukum dan dilakukan oleh orang yang mampu bertanggung jawab. ${ }^{11}$

Bersifat melawan hukum itu merupakan syarat mutlak untuk tindak pidana. Berkaitan dengan tindak pidana terdapat dua pandangan, yang pertama menurut pandangan kualitatif dibagi menjadi dua yaitu tindak pidana kejahatan yang bersifat rechts delict dan tindak pidana pelanggaran bersifat wet delict.

Recht delict maksudnya tindak pidana kejahatan sebagai perbuatan yang bertentangan dengan keadilan, terlepas dari apakah perbuatan itu diancam pidana dalam suatu Undang-Undang atau tidak, sedangkan wet delict merupakan suatu perbuatan yang dipandang sebagai tindak pidana apabila perbuatan itu baru disadari sebagai tindak pidana setelah adanya Undang-Undang yang mengatur. Tindak pidana bisa juga berarti suatu

\footnotetext{
${ }^{10}$ Ibid., hlm.42.

${ }^{11}$ Moeljatno, Op.Cit, hlm.84.
} 
perbuatan yang pelakunya dapat dikenakan hukum pidana sehingga disini pelaku dapat dikatakan merupakan subyek dari tindak pidana. ${ }^{12}$

Menurut R.Soesilo, yang dimaksud zina adalah persetubuhan yang dilakukan oleh laki-laki atau perempuan yang telah kawin dengan perempuan atau laki-laki yang bukan isteri atau suaminya. Supaya masuk pasal ini maka persetubuhan harus dilakukan dengan suka sama suka tidak boleh ada paksaan dari salah satu pihak. ${ }^{13}$

Lebih lanjut dijelaskan berkenaan dengan persetubuhan adalah peraduan antara anggota kemaluan laki-laki dan perempuan yang biasa dijalankan untuk mendapatkan anak, jadi anggota kemaluan laki-laki harus masuk ke dalam anggota kemaluan perempuan sehingga mengeluarkan air mani. ${ }^{14}$

Terkait dengan terminology kata "percobaan", selanjutnya akan diulas tentang pengertian percobaan. Undang-undang tidak memberikan deifinisi apa yang dimaksud percobaan itu, tetapi yang diberikan adalah ketentuan mengenai syarat-syarat supaya percobaan pada kejahatan itu dapat dipidana. Menurut arti kata sehari hari yang diartikan percobaan yaitu menuju kesesuatu hal akan tetapi tidak sampai pada hal yang dituju itu atau hendak berbuat sesuatu sudah dimulai akan tetapi tidak selesai.

Berdasarkan ketentuan Pasal 53 KUHP disebutkan mengenai syarat-syarat percobaan, yaitu mencoba melakukan kejahatan dipidana jika niat untuk itu telah ternyata dari adanya permulaan pelaksanaan dan tidak selesainya pelaksanaan itu bukan semata-mata disebabkan karena kehendak sendiri.

Supaya percobaan pada kejahatan dapat dipidana, harus memenuhi syarat-syarat sebagai berikut:

5.1.1. Niat sudah ada untuk berbuat kejahatan itu.

Unsur niat dilihat dari ajaran schuld pada umumnya yang dimaksud dengan niat adalah sama dengan pengertian hlm. 55

${ }^{12}$ Wiryono Prodjodikoro, Asas-Asas Hukum Pidana di Indonesia, Bandung: Eresco, 1989

13 R.Soesilo, Kitab Undang-Undang Hukum Pidana (KUHP): Beserta KomentarKomentarnya Lengkap Pasal Demi Pasal, Bogor: Politea, 1995, hlm. 209

${ }^{14}$ Ibid, hlm. 215 
sengaja (dolus) dalam semua gradasinya. pencantuman niat dalam perumusan percobaan merupakan suatu kekhususan". ${ }^{15}$ Jadi niat harus nyata dari si pembuat bahwa dia mempunyai niat atau kehendak nyata untuk melakukan kejahatan tersebut.

5.1.2. Orang sudah memulai berbuat kejahatan itu.

Permulaan pelaksanaan jika digunakan secara penafsiran tata bahasa yang dimaksud permulaan pelaksanaan adalah permulaan pelaksanaan tindakan dari niat (petindak), jika digunakan penafsiran secara sistematis maka permulaan pelaksanaan sama dengan pelaksanaan tindakan dari kejahatan $^{16}$.

Selanjutnya R.Soesilo menjelaskan mengenai permulaan pelaksanaan, yaitu sesuatu dapat dikatakan perbuatan tersebut sudah boleh dikatakan sebagai perbuatan pelaksanaan apabila orang telah mulai melakukan suatu anasir atau elemen dari peristiwa pidana, jika orang belum memulai dengan memulai dengan melakukan suatu anasir atau elemen ini maka perbuatannya masih harus dipandang sebagai perbuatan persiapan ${ }^{17}$.

5.1.3. Perbuatan kejahatan itu tidak jadi sampai selesai oleh karena terhalang oleh sebab-sebab yang timbul kemudian, tidak terletak dalam kemauan penjahat itu sendiri. ${ }^{18}$

Penjelasan mengenai perbuatan kejahatan tidak selesai bukan karena kehendaknya dapat disebabkan karena 4 (empat) macam yaitu:

5.1.3.1. Alatnya yang dipakai melakukan tidak sempurna 5.1.3.2. sama sekali (absolut ondeugdelijk middle).

\footnotetext{
${ }^{15}$ S.R.Sianturi, Asas-asas Hukum Pidana di Indonesia dan Penerapannya, Jakarta: Alumni Ahaem Pelete, 1982, hlm. 317.

${ }^{16}$ Ibid., hlm.317-318.

17 R.Soesilo, Kitab Undang-Undang Hukum Pidana (KUHP): ..., Loc.Cit..

${ }^{18}$ Ibid., hlm.69
} 
5.1.3.3. Alatnya yang dipakai melakukan kurang sempurna (relatief ondeugdelijk middle).

5.1.3.4. Obyek yang dituju tidak sempurna sama sekali (absolut ondeugdelijk object).

SR.Sianturi lebih lanjut menjelaskan mengenai unsur tidak selesainya perbuatan pidana bukan karena kehendak pelaku, yaitu yang tidak selesai adalah kejahatan atau kejahatan itu tidak terjadi sesuai dengan ketentuan Undang-Undang atau tidak sempurna memenuhi unsur-unsur dari kejahatan menurut rumusannya, dengan perkataan lain niat petindak untuk melaksanakan kejahatan tertentu yang sudah dinyatakan dengan tindakannya terhenti sebelum sempurna terjadi kesalahan itu, dapat juga dikatakan bahwa tindakan untuk merugikan sesuatu kepentingan hukum yang dilindungi oleh Undang-Undang hukum pidana itu terhenti sebelum terjadi kerugian yang sesuai dengan perumusan Undang-Undang. ${ }^{19}$

Jadi apabila orang berniat berbuat kejahatan dan ia telah mulai melakukan kejahatan itu akan tetapi karena timbul rasa menyesal dalam hati ia mengurungkan perbuatannya sehingga kejahatannya tidak sampai selesai maka ia tidak dapat dihukum karena percobaan pada kejahatan itu karena tidak selesainya kejahatan itu karena kemauan sendiri.

5.1.4. Obyek yang dituju kurang sempurna (relatief ondeugdelijk object).

Berdasarkan penjelasan di atas maka dapat ditarik suatu pengertian bahwa Percobaan Perzinahan adalah peraduan antara anggota kemaluan laki-laki dan perempuan yang biasa dijalankan untuk mendapatkan anak, jadi anggota kemaluan laki-laki harus masuk ke dalam anggota kemaluan perempuan sehingga mengeluarkan air mani yang dilakukan oleh lakilaki atau perempuan yang telah kawin dengan perempuan atau laki-laki

19 S.R.Sianturi, Asas-asas Hukum Pidana di Indonesia. ..Op.Cit. hlm. 324 
yang bukan isteri atau suaminya, yang mana niat untuk itu telah ternyata dari adanya permulaan pelaksanaan dan tidak selesainya pelaksanaan itu bukan semata-mata disebabkan karena kehendaknya sendiri.

\subsection{Kedudukan Hukum Percobaan Perzinahan dalam Praktik Peradilan}

Masih terdapat perbedaan pendapat mengenai bias atau tidak suatu pasal percobaan perzinahan digunakan dalam praktik peradilan. Hal ini karena sangat sulit untuk dilogikakan batasan-batasan konkrit perbuatan yang dapat dikategorikan sebagai perbuatan percobaan perzinahan. Sepertinya Undang-Undang perlu pembenahan karena pada saat suatu Undang-Undang dibahas dan dibicarakan oleh legislatif, semua berpendapat sudah baik dan sempurna, tetapi pada saat diundangkan, Undang-Undang tersebut langsung berhadapan dengan seribu macam masalah konkreto yang tidak terjangkau dan tak terpikirkan pada saat pembahasan dan perumusan"20.

Apabila merujuk pada pasal-pasal yang berkaitan dengan perzinahan dan percobaan dapat dikatakan bahwa percobaan perzinahan adalah perbuatan asusila dalam hal ini melakukan zina tetapi perbuatan tersebut tidak selesai bukan karena kehendak dari pelaku. Delik asusila dalam hal ini perzinahan termasuk dalam ruang lingkup delik aduan.

R. Soesilo menjelaskan mengenai delik aduan bahwa dalam prisnsipnya apabila terjadi peristiwa pidana maka pemerintah yang diwakili oleh Polisi, Kejaksaan, dan Kehakiman, tanpa permintaan dari yang kena peristiwa pidana itu segera bertindak melakukan pemeriksaan penuntutan dan memberikan hukuman kepada orang-orang yang bersalah, tetapi dari banyak peristiwa pidana itu ada beberapa jenis, hampir semuanya kejahatan yang hanya dituntut atas pengaduan (permintaan) dari orang yang kena peristiwa pidana. Peristiwa ini biasa disebut pula delik aduan. Alasan dari adanya delik aduan ini adalah bahwa dalam beberapa hal bagi orang yang bersangkutan lebih

${ }^{20}$ M. Yahya Harahap, Pembahasan Permasalahan dan Penerapan KUHAP: Penyidikan dan Penuntutan (Edisi Kedua). Jakarta: Sinar Grafika, 2009, hlm.12 
menguntungkan untuk tidak menuntut perkara itu dari pada keuntungan bagi pemerintah (masyarakat) jika dilakukan penuntutan.

Delik aduan dibedakan atas dua jenis yaitu, delik aduan absolut ialah delik (peristiwa pidana) yang selalu hanya dituntut apabila ada pengaduan seperti tersebut dalam pasal-pasal : 284 KUHP (perzinahan), 287 KUHP (bersetubuh dengan wanita dibawah umur diluar perkawinan), 293 KUHP (perbuatan cabul terhadap anak dibawah umur), 310 KUHP (pencemaran nama baik), 322 KUHP (membuka rahasia jabatan), 332 KUHP (membawa lari wanita), dan 369 KUHP (pengancaman). Dalam hal ini maka pengaduan diperlukan untuk menuntut peristiwanya. Oleh karena yang dituntut peristiwanya maka semua yang bersangkut paut (melakukan, membujuk, membantu) dengan peristiwa itu harus dituntut, jadi delik aduan ini tidak dapat dibelah. Seorang suami jika telah memasukkan pengaduan terhadap perzinahan (Pasal 284 KUHP) yang telah dilakukan istrinya, ia tidak dapat menghendaki supaya orang laki-laki yang telah berzina dengan istrinya itu dituntut, tetapi terhadap istrinya (karena ia masih cinta) jangan dilakukan penuntutan.

Delik aduan relatif, ialah delik (peristiwa pidana) yang biasanya bukan merupakan delik aduan, akan tetapi jika dilakukan oleh sanak keluarga yang ditentukan dalam Pasal 367 KUHP lalu menjadi delik aduan. Delik aduan relatif ini seperti tersebut dalam Pasal 367 KUHP (pencurian dalam keluarga), 370 KUHP (pemerasan dan pengancaman dalam keluarga), 376 KUHP (penggelapan dalam keluarga), 394 KUHP (penipuan dalam keluarga), 404 KUHP, dan 411 KUHP (menghancurkan atau merusak barang dalam keluarga. Dalam hal ini maka pengaduan itu diperlukan bukan untuk menuntut peistiwanya, akan tetapi untuk menuntut orangnya yang bersalah. Jadi delik aduan ini dapat dibelah. Seorang bapak yang barang-barangnya dicuri oleh dua orang anaknya yang bernama $\mathrm{A}$ dan $\mathrm{B}$, dapat mengajukan pengaduan hanya seorang saja dari kedua anak itu. ${ }^{21}$

\footnotetext{
${ }^{21}$ R.Soesilo, Kitab Undang-Undang Hukum Pidana (KUHP):..., Op.Cit., hlm.87
} 
Berdasarkan penjelasan tersebut maka perzinahan masuk dalam kategori delik aduan absolut, artinya tidak dapat dituntut apabila tidak ada pengaduan dari pihak suami atau istri yang dirugikan, dan semua pihak yang berbuat perzinahan tersebut tidak dapat dipisahkan dan semuanya harus dilakukan penuntutan secara hukum.

Perzinahan pada intinya diatur dalam Pasal 284 KUHP dengan spesifikikasi yaitu Pasal 284 ayat (1) ke-1 huruf a KUHP mengatur tentang laki-laki beristri yang berbuat zina, Pasal 284 ayat (1) ke-1 huruf b KUHP mengatur tentang perempuan bersuami yang berbuat zina, Pasal 284 ayat (1) ke-2 huruf a KUHP mengatur tentang laki-laki yang turut melakukan perbuatan (zina) sedang diketahui bahwa perempuan itu bersuami, Pasal 284 ayat (1) ke-2 huruf b KUHP mengatur tentang perempuan yang tiada bersuami yang turut melakukan perbuatan (zina) sedang diketahuinya bahwa laki-laki itu beristri. Berdasarkan penjelasan tersebut maka tindak pidana perzinahan yang tidak selesai bukan karena kehendak si pelaku yang dinamakan percobaan perzinahan juga masuk dalam kategori delik aduan.

Dalam praktik peradilan, upaya penegakan hukum dalam ranah hukum pidana berjalan dalam sebuah sistem yang disebut dengan sistem peradilan pidana (criminal justice system). Istilah tersebut untuk menunjukkan mekanisme kerja dalam penanggulangan kejahatan dengan mempergunakan dasar pendekatan sistem. Sistem peradilan pidana yang disebut juga dengan criminal justice process dimulai dari proses penyelidikan/penyidikan, penuntutan, dan pemeriksaan di dapan pengadilan, serta diakhiri dengan pelaksanaan pidana di lembaga pemasyarakatan. $^{22}$ Sistem peradilan pidana merupakan jaringan (network) peradilan yang menggunakan hukum pidana sebagai sarana utamanya, baik hukum pidana materiil, hukum pidana formil, maupun hukum pelaksanaan pidana.

22 R.Atmasasmita, Sistem Peradilan Pidana Indonesia (Criminal Justice System), Perspektif Eksistemsialisme dan Abolisionisme, Jakarta: Bina Cipta. 1996, hlm. 
Adapun sistem peradilan pidana secara umum, selalu melibatkan sub-sistem dalam ruang lingkup masing-masing yang dimulai dari institusi Kepolisian, Kejaksaan, Pengadilan, dan Lembaga Pemasyarakatan, serta Advokat/Pengacara sebagai penyeimbang, yang dapat digambarkan sebagai berikut :

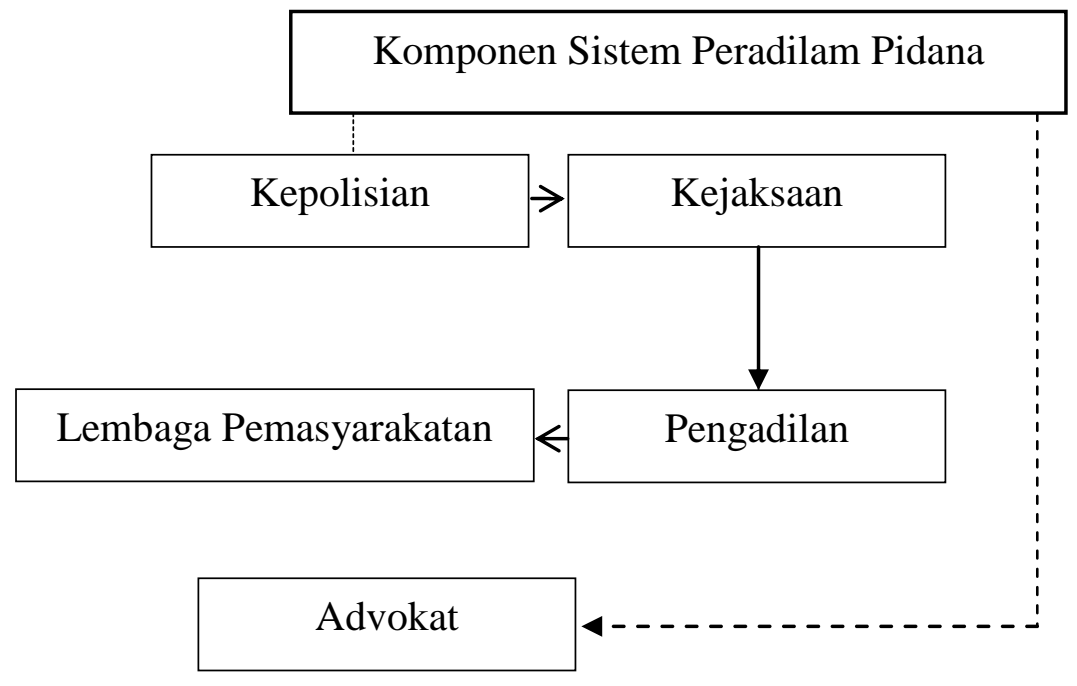

\section{Bagan 1. Komponen Sistem Peradilam Pidana}

Berdasarkan penjelasan di atas tentang pengertian percobaan perzinahan dikaitkan dengan logika praktik peradilan, maka sangat besar kemungkinan jika pelaku sistem peradilan pidana dalam rangka penegakan hukum terhadap tindak pidana percobaan perzinahan mengalami perbedaan pendapat atau pandangan. Dari sisi normatif, meskipun percobaan perzinahan sulit dilogikakan berkenaan dengan batasan-batasan perbuatan yang dapat dikategorikan sebagai perbuatan perzinahan, tetapi pada intinya perzinahan adalah tindak pidana yang masuk dalam kategori kejahatan.

Selama tidak diatur secara tegas dalam KUHP berkenaan dengan percobaan kejahatan yang tidak dapat dipidana, maka kejahatan tersebut masih dapat dilakukan penuntutan dan dapat dipidana. Begitu pula dengan delik perzinahan dalam KUHP, tidak ada aturan secara tegas berkenaan dengan tidak dapat dipidananya kejahatan percobaan perzinahan yaitu Pasal 284 KUHP dikaitkan dengan Pasal 53 ayat (1) 
KUHP, sehingga pasal percobaan perzinahan secara yurudis normatif tetap dapat dikenakan.

Sejalan dengan penjelasan tersebut apabila lihat pada Pasal 54 KUHP yang menyatakan bahwa "mencoba melakukan pelanggaran tidak dipidana”, yang secara eksplisit juga menyatakan bahwa pada delik kejahatan dapat digunakan pasal percobaan, kecuali ada beberapa kejahatan yang sudah ditentukan oleh Undang-Undang secara tegas diatur dalam KUHP yang percobaannya tidak dapat dipidana seperti percobaan menganiaya. $^{23}$ percobaan menganiaya binatang. ${ }^{24}$ dan percobaan perang tanding. ${ }^{25}$ Bertitik tolak pada ketentuan tersebut tentunya penggunaan Pasal percobaan perzinahan tersebut tetap dapat disangkakan dan dipidana.

Tetapi dalam praktik peradilan tentunya tidak sesederhana demikian, proses penegakan hukum tidak boleh kaku dengan bunyi peraturan perundang-undangan. Banyak persoalan yang harus dikaji lebih dalam sampai batas mana pasal percobaan perzinahan dapat dilogikakan. Apakah ketika seseorang digerebek dalam sebuah hotel kemudian dilakukan visum tidak ada sperma dan tidak ditemukan tanda-tanda hubungan seksual dapat dikenakan pasal percobaan perzinahan? tentunya hal ini akan menjadi diskusi yang berkepanjangan yang perlu dibuktikan secara konkrit dalam sebuah sidang pengadilan.

Adanya reorientasi cara pandang publik terhadap penegakan hukum harus dibarengi dengan aparat penegak hukum yang responsif untuk mewujudkan penegakan hukum yang tidak hanya menggunakan teori formal-positivistis. Keadaan semacam ini sepertinya telah diramalkan oleh Satjipto Rahardjo yang sejak jauh hari menulis tentang hukum progresif yang bertujuan mewujudkan alternatif bagi pendekatan dominan dalam interpretasi hukum di Indonesia, yaitu pendekatan yang dianggap formalistik dan kurang memperhatikan substansi keadilan. Satjipto Rahardjo menjelaskan bahwa kepastian hukum terlalu

\footnotetext{
${ }^{23}$ Lihat Pasal 351 ayat (5) Kitab Undang-Undang Hukum Pidana.

${ }^{24}$ Lihat Pasal 302 ayat (3) Kitab Undang-Undang Hukum Pidana

${ }^{25}$ Lihat Pasal 184 ayat (5) Kitab Undang-Undang Hukum Pidana
} 
didewakan, padahal seharusnya hukum lebih manusiawi, akar masalah dari situasi ini bersumber dari keadaan hukum tertulis sendiri, yang dengan gampang akan menghasilkan tragedi hukum. ${ }^{26}$

Saat ini aparat penegak hukum dituntut untuk tidak sekedar melaksanakan tugasnya dengan hanya bertumpu pada satu kaki melalui pendekatan Undang-Undang saja, dengan asal sekedar memenuhi unsur ketentuan bunyi pasal maka dikatakan sudah terpenuhi semua syaratnya. Aparat penegak hukum sekarang harus juga menggunakan pendekatan kasus dengan menelaah beberapa kasus untuk bahan referensi, serta pendekatan konseptual dengan beranjak dari pandangan dan doktrin yang berkembang yang nantinya dapat melahirkan ide dan konsep hukum yang relevan.

Sejatinya aparat penegak hukum diminta untuk tidak hanya terpaku pada norma hukum apa yang dilarang atau dianjurkan, tetapi diminta berpikir lebih jauh lagi sampai ke batas akibat apa yang dapat ditimbulkan dari penegakan hukum terhadap larangan atau pun anjuran norma hukum tersebut. Para aparat penegak hukum diharapkan bisa mendobrak paham positivisme yang kaku dengan lebih mengedepankan nilai-nilai keadilan dan hati nurani namun tetap dalam koridor hukum yang berlaku.

Menyelaraskan pemikiran antara bunyi pasal dalam UndangUndang dengan praktik peradilan, termasuk dalam penggunaan Pasal percobaan perzinahan terutama berkaitan dengan batasan konkrit antara unsur permulaan pelaksanaan dan perbuatan persiapan, maka ketentuan dalam KUHP sudah harus ada revisi terkait klausul Pasal percobaan perzinahan, berupa pengaturan secara khusus dalam delik tersendiri dengan batasan-batasan yang jelas dan tegas untuk lebih menjamin sebuah kepastian hukum yang berkeadilan dalam praktik peradilan.

\footnotetext{
${ }^{26}$ Satjipto Rahardjo dalam Andriaan Bedner, Seri Tokoh Hukum Indonesia Satjipto Rahardjo dan Hukum Progresif Urgensi dan Kritik: Suatu Pendekatan Elementer Terhadap Negara Hukum, Jakarta: Epistema Institute, 2011, hlm.139-140
} 


\section{Kesimpulan}

Secara legalitas formal Pasal percobaan perzinahan termasuk kategori tindak pidana kejahatan. Selama tidak diatur secara tegas dalam KUHP berkenaan percobaan kejahatan yang tidak dapat dipidana, maka kejahatan tersebut secara yuridis normatif tetap dapat dikenakan, namun demikian secara praktik peradilan harus dikaji lebih jauh lagi sampai batas mana Pasal percobaan perzinahan dapat dilogikakan secara nalar dan dibuktikan, sehingga hal ini kerap menjadi perdebatan. Hal inilah yag membuat harus ada revisi konkrit terkait klausul pasal percobaan perzinahan, berupa pengaturan secara khusus dalam delik tersendiri dengan batasan yang jelas dan tegas untuk lebih menjamin sebuah kepastian hukum yang berkeadilan. 


\section{DAFTAR PUSTAKA}

\section{Peraturan Perundang-undangan}

Kitab Undang-Undang Hukum Pidana.

\section{Literatur Ilmiah}

Atmasasmita, R, Sistem Peradilan Pidana Indonesia (Criminal Justice System), Perspektif Eksistemsialisme dan Abolisionisme, Jakarta: Bina Cipta. 1996.

Basar, M. Sudrajat, Tindak Tindak Pidana Tertentu di Dalam KUHP, Bandung: CV Remaja Karya, 1986.

Hidayat, H. Iman, " Analisis Normatif Tindak Pidana Perzinahan Dilihat dalam Perspektif Hukum Islam”, Jurnal Ilmiah Universitas Batanghari Jambi Vol.16 No.1 Tahun 2016.

Harahap, M. Yahya, Pembahasan Permasalahan dan Penerapan KUHAP: Penyidikan dan Penuntutan (Edisi Kedua). Jakarta: Sinar Grafika, 2009.

Marzuki, Peter Mahmud, Penelitian Hukum, Jakarta: Kencana Prenada Media Group, 2008.

Moeljatno, Asas Asas Hukum Pidana, Jakarta: Rineka Cipta, 2002.

Nita Triani, Eko Raharjo dan Dona Raisa Monica, "Analisis Putusan Hakim dalam Membebaskan Pelaku yang Didakwa Melakukan Tindak Pidana Perzinahan (Studi Putusan Nomor: 89/Pid/2017/Pt.Tjk)", Jurnal Skripsi Fakultas Hukum Universitas Lampung, 2018.

Prodjodikoro, Wiryono, Asas-Asas Hukum Pidana di Indonesia, Bandung: Eresco, 1989.

Pasek Diantha, I Made, Metodologi Penelitian Hukum Normatif Dalam Justifikasi Teori Hukum, Jakarta: Prenada Media Group, 2017.

Rahardjo, Satjipto, dalam Andriaan Bedner, Seri Tokoh Hukum Indonesia Satjipto Rahardjo dan Hukum Progresif Urgensi dan Kritik: Suatu Pendekatan Elementer Terhadap Negara Hukum, Jakarta: Epistema Institute, 2011.

.Soesilo, R, Kitab Undang-Undang Hukum Pidana (KUHP): Beserta Komentar-Komentarnya Lengkap Pasal Demi Pasal, Bogor: Politea, 1995.

Sianturi, S.R, Asas-asas Hukum Pidana di Indonesia dan Penerapannya, Jakarta: Alumni Ahaem Pelete, 1982. 